\title{
AUKŠTYBINIŲ PASTATŲ ATSIRADIMAS IR JŲ RAIDA
}

\author{
Josifas Parasonis, Ernestas Gaudutis \\ Architektūros inžinerijos katedra, Vilniaus Gedimino technikos universitetas, \\ Saulètekio al. 11, LT-10223 Vilnius, Lietuva, \\ El.paštas: josifas@ar.vgtu.lt; ernestas.gaudutis@vilnius.lt
}

Itteikta 20090315

\begin{abstract}
Santrauka. Nors aukštybinių pastatų vystymosi raida skaičiuoja antrąj šimtmetį, kol kas nèra visuotinai priimto kriterijaus jiems apibūdinti. Skirtingos yra ir jų atsiradimo priežastys bei vystymasis (urbanistiniu, paveldo išsaugojimo ir kt. požiūriais) įvairiuose pasaulio kraštuose. Remiantis kai kurių pasaulio šalių normatyvinių dokumentų nuostatų ir literatūros šaltinių analizès rezultatais šiame darbe pabandyta pasiūlyti kriterijus aukštybiniams pastatams paženklinti. Analizuojami jų atsiradimo skirtinguose pasaulio žemynuose raidos ypatumai, šių pastatų, išdèstytų įvairiuose pasaulio miestuose, architektūrinių planinių sprendinių, urbanistinių požiūrių skirtumai, aukštybinių pastatų ịtaka miestų raidai.
\end{abstract}

Reikšminiai žodžiai: aukštybinis pastatas, dangoraižis, kriterijai, architektūriniai ir konstrukciniai ypatumai, miesto siluetas.

\section{İvadas}

Apibūdinant aukštybinius pastatus, ̨ॄvairiuose normatyviniuose dokumentuose ir literatūros šaltiniuose siūlomi skirtingi kriterijai. Todèl nesutariama dèl šių pastatų atsiradimo apskritai arba pirmojo tokio pastato pastatymo ịvairiose šalyse. Ši aplinkybẻ neleidžia tiksliai ịvardinti tyrimo objekto atitinkamoje mokslineje literatūroje, aukštybinius pastatus grupuoti, analizuoti ir vertinti. Skirtingi autoriai remiasi skirtingų literatūros šaltinių pateikiamais kriterijais šiems pastatams apibūdinti. Šių pastatų atsiradimo priežastys ir raida skirtinguose pasaulio kraštuose turi savo ypatumų, kurie neretai taip ir lieka neįvertinti, nagrinèjant aukštybinius pastatus ịvairiais aspektais. Pasaulio ir mūsų šalies vystymosi praktika byloja apie vis didejjančią aukštybinių pastatų ịtaką miestų vizualiniam tapatumui, kultūros paveldui, žmonių gyvenimo sąlygoms. Aukštybiniai pastatai transformuoja architektūrinius planinius pastatų sprendinius, stimuliuoja naujų medžiagų, konstrukcinių sprendinių ir technologijų atsiradimą. Ju vystymuisi ittaką daro techninès bei technologinès ir ekonominès galimybès, miestų vystymosi urbanistiniai reikalavimai, kurie turi tiesiogini poveiki susiklosčiusiems vaizdams, miesto siluetui, lokalių er- dvių ỉvaizdžio kaitai. Šie pastatai neretai tampa naujaisiais miestų simboliais, iškilusiais naujoje globalizacijos ir aukštųjų technologijų epochoje. Šiame darbe aptariama aukštybinių pastatų samprata, jų atsiradimo ìvairiose šalyse priežastys, ypatumai, raida.

\section{Aukštybinių pastatų samprata}

Siekiant apibūdinti aukštybinius pastatus šiandien dažniausiai taikomi aukščio kriterijai, kurie nurodomi metrais virš žemès paviršiaus arba aukštų skaičiumi. Vienas pagrindinių šaltinių yra ịvairių šalių normatyviniai dokumentai. Lietuvos Respublikoje, vadovaujantis STR 1.01.06:2002 „Ypatingi statiniai“, aukštybiniu pastatu laikomas statinys, kurio aukštis nuo žemės paviršiaus iki aukščiausio konstrukcijos taško siekia $30 \mathrm{~m}$. Statybos techniniame reglamente STR 2.02.01:2004 „Gyvenamieji pastatai“ itvirtinta nuostata, kad aukštybinis pastatas yra toks, kurio viršutinio aukšto, įskaitant mansardinį, grindų paviršiaus altitudè yra 26,5 m ir daugiau. Aukštybiniu pastatu išdèstymo specialiųu planų rengimo taisyklèse nurodytas minimalus jų aukštis nuo sklypo paviršiaus 
vidutinės altitudės yra lygus ar viršija $30 \mathrm{~m}$, išskyrus atvejus, kai miesto savivaldybės taryba yra nustačiusi kitą pastato aukštị. Vilniaus mieste šis aukštis tarybos sprendimu nustatytas $35 \mathrm{~m}$ (12 aukštų). Matome, kad net tarp Lietuvoje galiojančių skirtingų norminių aktų, nurodančių aukštybinių pastatų aukštį, egzistuoja nedideli prieštaravimai. Lietuvoje, kaip ir daugelyje užsienio valstybių, aukštybinio pastato sąvoką lemia ugniagesių turimos technikos, tokios kaip kopèčios ir automobiliniai keltuvai, maksimalus darbinis aukštis.

Vokietijos Federacinejje Respublikoje aukštybinių pastatų minimalus aukštis yra $22 \mathrm{~m}$ virš žemès paviršiaus (Eisele, Kloft 2003). Itvairiose JAV valstijose ir miestuose statybinès normos apibrèžia skirtingą šių pastatų aukštį. Kalifornijos valstijos statybos techniniai reglamentai aukštybinius pastatus apibrèžia kaip turinčius bent vieną žmonių naudojamą aukštą, esantị aukščiau nei $23 \mathrm{~m}$ (aukštis matuojant nuo žemiausio aukšto, turinčio iejjimą i pastatą, grindų). Masačiusetso valstijoje aukštybiniais pastatais laikomi aukštesni nei $21 \mathrm{~m}$. Čikagoje aukštybiniais laikomi aukštesni kaip $24 \mathrm{~m}$ aukščio pastatai. Hjustone galiojantys statybos normatyviniai dokumentai aukštybinius pastatus j̣vardina aukštesnius nei $23 \mathrm{~m}$, matuojant pastato aukštị nuo pirmo aukšto grindų lygio. Pagal Rusijos Federacijos statybos normas aukštybiniais laikomi pastatai, aukštesni nei 75 m (30 aukštų) (Дыховичный et. al. 2007). Ukrainoje aukštybiniais laikomi aukštesni nei 73,5 m (25 aukštų) pastatai. Skirtingų šalių statybos normos nepateikia bendro atsakymo ị mūsų nagrinèjamą klausimą, todèl jau pradiniu analizès etapu atsiranda pagrịstas klausimas, ką vis dèl to reikètų vadinti aukštybiniu pastatu. Ar aukščio kriterijus yra vienintelis rodiklis, leidžiantis apibrèžti aukštybinius pastatus?

„Dangoraižis“ savo laiku buvo jūrinis terminas, kuris anksčiau reiškè aukštą laivo stiebą arba pagrindinę burę, tačiau XIX a. pabaigoje jis igavo visai kita reikšmę. Pirmiausiai pradètas vartoti šnekamojoje kalboje kaip priešingybẻ šalia vyraujančiam žemesniam užstatymui ir galèjo būti vartojamas nepriklausomai nuo nagrinejjamų pastatų aukščio. Taip buvo vadinami tam tikroje vietovejje dominuojantys išskirtinio aukščio pastatai. Užstatymo kontekstas iki šių dienų išliko reliatyviu dydžiu, su kuriuo susieti šią sąvoką yra gana sudètinga. Seniausias žinomas „dangoraižio“ apibrèžimas buvo pateiktas dar $1891 \mathrm{~m}$. Maitlando Amerikos slengo žodyne, kuriame jis buvo apibrèžtas tiesiog kaip labai aukštas pastatas. Reikètų pabrežti, kad ilgą laiką nebuvo aiškios diferenciacijos tarp „aukštybinio pastato “ ir „dangoraižio" sąvokų. Pastačius Home Insurance biurų pastatą, , ,dangoraižio" sąvoka kai kurių architektūros istorikų pradètas tiesiogiai sieti su ketaus karkaso išradimu, atliktu paskutiniais XIX a. dešimtmečiais.

Pagrindiniu kriterijumi, apibrèžiančiu aukštybinius pastatus, tapo nauja konstrukcinè sistema ir jos medžiagos, tai suteike naujų galimybių planuoti vidines pastatų erdves, leido itin padidinti jų aukštingumą. Tačiau dalis to meto aukštų pastatų toliau buvo statomi naudojant iki tol ịprastą mūrinių laikančiųjų sienų sistemą, todèl čia neišvengiama netikslumų. XIX a. pabaigoje „dangoraižiais“ pradetti vadinti 10 ir daugiau aukštų turintys pastatai (Коуэн 1982). Pirmą kartą istorijoje dingsta šios sąvokos neapibrèžtumas ir šiuos pastatus apibrèžiantys aukščio kriterijai łgauna konkrečią skaitinę reikšmę, kurios išraiška bėgant laikui keitėsi. Tačiau kai kurie architektūros istorikai aukštybinių pastatų apibūdinimo kriterijaus nesieja su konkrečiu pastato aukščiu. Carl W. Condit suvokdamas, kad „dangoraižis“ išlieka aiškiai neapibrežta sąvoka, savo darbuose šị terminą taikè dideliems komerciniams, visuomeniniams ar gyvenamiesiems pastatams, nepaisant jų formos ar aukščio (Korom 2008). Tačiau vadovautis funkciniais, tipologiniais aspektais yra netikslinga. Nes nuo pat atsiradimo aukštybiniai pastatai atliko gyvenamųjų namų, biurų, viešbučių ir kitas jiems priskirtas funkcijas. Aukštis kaip lemiamas kriterijus aukštybiniams pastatams buvo pasirinktas ne veltui. Jis tampa charakteringu veiksniu, nulemiančiu vizualini pastato poveiki miesto siluetui ir jo funkcines, technologines ypatybes, kurios itin skyrèsi nuo būdingų mažaaukštei statybai. Atsiradę liftų irangos, šildymo, vandens tiekimo ir kiek vèliau prieš Antrąji pasaulinį karą novatoriški oro kondicionavimo sistemos sprendiniai leido užtikrinti tinkamą šių pastatu funkcionavimą, itin padidinus ju aukštingumą, todèl šie išradimai pradèti sieti su aukštybinio pastato sąvoka. 1929 m. publikuotoje knygoje The History of the skyscraper Francisko mujica teige, kad tik pastatus, turinčius daug aukštų, plieninį karkasą ir greitus elektrinius liftus, galima vadinti „dangoraižiais“. Vèlesniais laikais taip pat pasitaikydavo bandymų „dangoraižio“ sąvoką sieti su plieniniu karkasu. 1930 m. išleistoje W. C. Clark ir J. L. Kingston knygoje The Skyscraper dangoraižiais kaip prieš $40 \mathrm{~m}$. siūlyta laikyti pastatus, turinčius plieninį karkasą. Autorių manymu, tai ir yra tikrieji dangoraižiai. Šiam teiginiui pritarè ir architektūros istorikas Donald Martin Reynolds, kuris 1984 m. analogiškai apibrèžè „dangoraižius“ (Korom 2008). XX a. 
7-ajame ir 8-ajame dešimtmečiuose susiformavo nauja „dangoraižio“ kaip išskirtinio aukščio aukštybinio pastato samprata. Ji jau nebuvo „aukštybinio pastato“ sąvokos sinonimas. Šiandien didelio aukščio pastatams apibrèžti pradètas vartoti terminas „dangoraižis“ arba atsiradęs „ypač aukštų pastatų“ terminas, tačiau įvairių šalių normose jie nèra išskiriami. Šiuos terminus apibrěžia tik kai kurios visuomeninės organizacijos ir pavieniai mokslinès literatūros šaltiniai, vadovaudamiesi skirtingais aukščio kriterijais. Aukštybinių pastatų architektūros tyrinètojas A. A. Svetikovas sudarè pastatu aukščio skalę, pagal kurią pastatai, kurių aukštis siekia iki $120 \mathrm{~m}$ (30-35 aukštų), priskiriami aukštybinių pastatų grupei, o aukštesni nei 120 m (40 aukštų) - dangoraižiams. Pastarųjų riba motyvuojama tuo, kad patys žemiausi debesys praplaukia būtent šiame aukštyje.

Bègant laikui, keitėsi ir aukštybinio pastato sąvoka. Architektus ir inžinierius vienijančios įvairios organizacijos, tokios kaip ASCE (American Society of Civil Engineers) ir CIB (The International Council for Research and Innovation in Building and Construction), dèl aukštybinių pastatų prièmė kai kurias rekomendacijas. 1976 m. vykusiame CIB simpoziume priimta bendra pastatų klasifikacija metrais, pagal kurią pastatai iki $30 \mathrm{~m}$ priskiriami prie padidinto aukštingumo. Pastatai iki 50, 75 ir $100 \mathrm{~m}$ atitinkamai ivardinami I, II, III kategorijos daugiaaukščiais, o aukštesni nei $100 \mathrm{~m}$ - aukštybiniais. Pastebime, kad aukštybiniai pastatai klasifikuojami pasitelkiant metrus, o ne aukštų skaičių. Pagrindinè tokio pasirinkimo priežastis yra tai, kad vienodo aukščio pastatų aukštingumas neretai būna skirtingas priklausomai nuo pastato paskirties ir nacionalinių projektavimo normų reikalavimų. Tačiau pateiktas $C I B$ klasifikavimas nèra kol kas visuotinai priimtas pasaulio šalių normatyviniais dokumentais ir skirtingose šalyse, kaip jau minèta, priklausomai nuo susiklosčiusių projektavimo tradicijų ir normų traktuojamas ivvairiai. Tarptautinè Council on Tall Buildings and Urban Habitat organizacija, įsikūrusi Ilinojaus universitete Čikagoje ir užsiimanti aukštų pastatų tyrimais, aukštybinius pastatus apibrèžia kaip turinčius daugiau kaip 14 aukštų arba viršijančius $50 \mathrm{~m}$. Ypač aukštų pastatų grupei priskiriami aukštesni nei 300 m (Council ... 2009). Nekilnojamojo turto bendrove Emporis Standarts Commitee šiuo metu aukštybiniais laiko 12-39 aukštų pastatus, kurių aukštis yra 35-100 m. Žinomas čekų inžinierius, mokslininkas J. Kozak (Козак 1986) savo darbuose aukštybiniais laiko 10-100 aukštų ir aukštesnius pastatus. Toks apibrěžimas apima aukštybinių pastatų pirmtakus, staty- tus dar iki XIX a. pabaigos, ir aukščiausius šiuolaikinius pastatus. ASHRAE (American Society of Heating, Refrigerating and Air-Conditioning Engineers) - tarptautinè organizacija, vienijanti fizinius asmenis ir kompanijas, dirbančius šildymo, vedinimo, oro kondicionavimo ir šaldymo srityse. Techninis komitetas aukštybinius pastatus apibrèžia kaip aukštesnius nei $91 \mathrm{~m}$. Vadovaujantis inžineriniais kriterijais šie pastatai apibrèžiami kaip vertikali konstrukcija, kuriai vėjo apkrova yra daug reikšmingesnè negu kitokio pobūdžio poveikiai. Tačiau taip galima apibrež̌ti ne tik pastatus, bet ir tokius statinius kaip televizijos ar radijo bokštai. NFPA (National Fire Protection Association) - JAV įsikūrusi organizacija, kurianti ir tobulinanti normatyvinę bazę, susijusią su gaisrine sauga. Šios organizacijos normatyviniuose dokumetuose aukštybiniais yra laikomi aukštesni nei $23 \mathrm{~m}$ pastatai, kurių aukštis matuojamas nuo žemiausios vietos, privažiuojamos gaisrine mašina. Toks apibrèžimas siejamas su aukščiu, kuri gali pasiekti ugniagesių kopėčios. Gaisras, vykstantis aukščiau esančiose patalpose, turi būti gesinamas iš vidaus, tam numatant atitinkamas priemones. Confederation of Fire Protection Association-Europe aukštybinius pastatus yra apibrèžusi kaip aukštesnius nei $22 \mathrm{~m}$. International Code Council organizacija, siekianti užtikrinti pastatų patikimumą ir realizuoti priešgaisrines priemones, savo normatyviniuose dokumentuose šiuos pastatus apibrèžia kaip aukštesnius negu $23 \mathrm{~m}$. Daugelyje JAV valstijų ir miestų vadovaujamasi organizacijos sukurtomis „Tarptautinèmis statybos normomis" (International Building Code), kuriose yra nurodomas minètas pastatų aukštis. Remiantis išdėstyta medžiaga, matyti, kad mūsų šalies normatyvinių dokumentų nuostata artima kitų šalių požiūriui, kai naudojami aukštybinių pastatų apibrēžimo kriterijai glaudžiai susiję su gaisrinès saugos reikalavimais. Aukštybinio pastato apibrèžime nèra bendros visuotinai priimtos arba tarptautinemis normomis itteisintos nuomonès, todèl atlikus analizę siuloma aukštybiniais pastatais laikyti $30 \mathrm{~m}$ (10-12 aukštų) ir aukštesnius pastatus, matuojant nuo žemès paviršiaus, tai yra būdinga daugumai anksčiau minètų šaltinių bei Lietuvos Respublikoje galiojančių normatyvinių dokumentų nuostatoms.

\section{Aukštybinių pastatų raida}

\subsection{Atsiradimas}

Aukštybinių pastatų atsiradimo klausimas buvo aktualus visais laikais ir jị nagrinėjo nemažai achitektūros 
teoretikų, daug knygų, straipsnių yra skirtų minètai temai, tačiau taip ir nèra bendros pagrịstos nuomonès, kada atsirado pirmasis aukštybinis pastatas. Kai kurie aukštybinių pastatų atsiradimą sieja su Senovès Egipto piramidemis ar Babilono zikuratais ar kitais senovès civilizacijoms būdingais sakraliniais statiniais. Daugiaaukščiai gyvenamieji namai žmonijos istorijoje yra žinomi jau nuo senovés Romos, kur jie buvo vadinami insulae. Ši sąvoka kilo iš lotyniško žodžio insula, reiškiančio salą. Iš paukščio skrydžio šie pastatai atrodè panašūs i salas, užimančias ištisus miesto kvartalus, ir buvo skirti žemiausios bei vidutinès klasės roménams apgyvendinti. Dažniausiai jų atsiradimo priežastimi laikoma didžiųjų imperijos miestų, tokių kaip Roma, Ostija, urbanizacija, kuri lèmé dideli gyvenamojo ploto poreikį. Tuo metu gyvenamųjų namų aukštingumas paprastai siekdavo 5-6 aukštus, kartais pasitaikydavo ir aukštesnių, tačiau priešingai negu vèlesniais laikais daugiaaukščiai pastatai nedominavo miestų siluetuose. Tankẻjant miestų užstatymui ir naudojant netinkamas medžiagas, atsirado pavojus kilti gaisrams. Dèl prastos statybos darbų kokybės neretai pasitaikydavo griūčių, todèl Romos imperatoriai, noredami išvengti aukų, nustate įvairius aukščio apribojimus, kurie dèl finansinių sumetimų pastatų valdytojų būdavo sąmoningai ignoruojami, neatsižvelgiant i galimus tragiškus padarinius (Коуэн 1982a). Ankstyvosios daugiaaukštès statybos pavyzdžiai taip pat sutinkami Shibam mieste, esančiame Jemene, kuris garsejja kaip „seniausias dangoraižiu miestas pasaulyje“ arba, kaip kartais jis yra vadinamas, tiesiog „dykumos Manhetenas“. Tai kartu vienas ankstyvųju urbanistinio planavimo pavyzdžių, kai buvo panaudotas vertikalių konstrukcijų principas. Koncentruotas užstatymas daugiaaukščiais pastatais buvo nulemtas išskirtinai miesto geografinès padèties ir gynybinių klausimų (Foundation et al. 2007). Šių pastatų aukštingumas svyravo nuo 5 iki 11 aukštų.

Daugiaaukščių pastatų statybą XVII a. Edinburge lèmè tokios priežastys. Miesto plètra buvo apribota dar nuo viduramžių išlikusių fortifikacinių ịtvirtinimų, todèl, esant ribotam žemès plotui, gyvenamieji pastatai buvo priversti stiebtis aukštyn. Paprastai šių pastatų, turinčių mūrines laikančiąsias sienas, aukštingumas siekdavo 11 aukštų, tačiau literatūros šaltiniuose galima sutikti duomenų, kad pasitaikydavo ir 14 aukštų. Daugiaaukščiai pastatai netrukus pradejo dominuoti miesto siluete, priešingai negu kituose pasaulio miestuose, kur industrializacijos laikotarpiu dominavo gamyklų kaminai arba bažnyčių bokštai. Vadovaujantis pasirinktu aukštybinių pastatų apibrèžimu, galima teigti, kad jie atsirado būtent šiame mieste. Statybos procesą paspartino miestą užplūdusi imigrantų iš Airijos banga, kuri siejama su industrine revoliucija. Šie pokyčiai itin padidino gyventojų skaičių ir koncentraciją Europos miestuose. Tai prasidèjo XVIII a. viduryje, tęsèsi iki pat XIX a., kada šį reiškinị lydèjo ne mažesnis urbanizacijos tempas. Miestų augimą pirmiausiai lèmé didelis naujos statybos būstų, skirtų apgyvendinti darbininkams, poreikis (Коуэн 1982b). Priešingai nei Edinburge, kituose Europos miestuose nebuvo veržiamasi aukštyn, nepaisant anksčiau minètos situacijos. Pagrindine priežastimi buvo tai, kad naujieji pramonès miestai plètėsi nevaržomai, o senieji jau Renesanso laikotarpiu buvo perkopę gynybinių itvirtinimų ribas. Šie faktai galètų atsakyti ị klausimą, kada aukštybinè statyba prasidèjo Europoje. Pramoninè revoliucija aukštybinių pastatų raidai turèjo ir kitą nemažiau svarbią reikšmę. XIX a. Anglijoje ir Prancūzijoje pradèti statyti pramoniniai pastatai su karkasine konstrukcine sistema, kurios konstrukciniai elementai buvo iš ketaus. Tačiau tuo metu niekas net nenumané apie galimybę ji pritaikyti aukštybiniams pastatams. XX a. pradžioje šį metalą pakeitè atsiradęs statybinis plienas.

\subsection{Aukštybinių pastatų raida JAV}

Analizuojant skirtingus literatūros šaltinius aukštybinių pastatų atsiradimas JAV sukelia mažiau prieštaravimų. Pirmieji aukštybiniai pastatai naujajame žemyne atsirado XIX a. pabaigoje Čikagoje kaip naujas biurų pastatų tipas, sietinas su intensyvios urbanizacijos metais vykstančia didžiųjų JAV miestų transformacija. Nors plytos, betonas civilizacijų istorijoje egzistavo ir anksčiau, tačiau tik XIX a. pabaigoje technologijos suteikè galimybę statyti vis aukštesnius pastatus. Nauji pastatai, akcentuojantys pelną ir naujas technologijas, buvo glaudžiai susiję su verslo poreikiais. $1885 \mathrm{~m}$. pastačius 10 aukštų Home Insurance biurų pastatą, "dangoraižio“ sąvoka kai kurių architektūros istorikų tiesiogiai pradèta sieti su ketaus karkaso išradimu, atliktu paskutiniais XIX a. dešimtmečiais. Tai suteikè naujų galimybių planuoti vidines pastatų erdves ir leido itin padidinti jų aukštingumą. Pagrindinis naujų pastatų bruožas buvo aukštis, kuris, didejjant žemès sklypų kainai, atrodẻ logišku susidariusios situacijos sprendimo būdu. <...> aukštis tapo charakteringu pastato veiksniu, nulemiančiu jo funkcines ir technologines ypatybes, kurios labai skyrèsi nuo büdingu mažaaukštei statybai (Коуэн 1982). Novatoriški konstrukciniai sprendiniai ir atsiradusios naujos statybinès medžia- 
gos padarè didelę ịtaką aukštybinių pastatų išvaizdai. Aukštybiniai pastatai keldavo naujų inžinerinių ir technologinių problemų, kartais net reikalavo sukurti naujas technologijas. Iki XIX a. pastatai, aukštesni nei 6 aukštų, buvo gana reti, tačiau jie turèjo vieną pagrindinị trūkumą - daug laiptų pakopų, tai kèlè rimtų nepatogumų gyventojams. Situacija pasikeite $1853 \mathrm{~m}$. Elishai Otis sukūrus keleivinị liftą, kuris pirmą kartą buvo įrengtas dar 1857 m. E. V. Haughworth \& Co prekybos centre Niujorke (Коуэн 1982b). Nors daugiaaukščiai pastatai egzistavo ir anksčiau, tačiau didelis jų aukščio augimas, kurị paskatino naujos pastatų konstrukcinès sistemos, tapo įmanomas tik tobulejjant pastatų inžinerinèms sistemoms.

Nauji biurai, esantys centrineje miesto dalyje, i̇monėms tapo patrauklia vieta vystyti verslą, suteikè pranašumą prieš konkurentus ir leido igyti reikiamus ryšius, gauti būtiną informaciją, sudarè galimybę sukurti patikimos, klestinčios kompanijos įvaizdį. Statytojas, padidindamas projektuojamo pastato aukštị ir parinkdamas tam ekonomiškas konstrukcijas, galëjo tikètis gauti papildomų pajamų, kurias lèmè tiesioginis ryšys, egzistuojantis tarp pastato aukščio ir nuomojamų patalpų ploto (Willis 1995). Reikètų paminèti, kad JAV biurai ir apartamentai didelio aukštingumo pastatuose paprastai būdavo nuomojami, o ne parduodami kaip kitose šalyse, taip jie atnešdavo pastato savininkui dideles pajamas. Didžiausią ịtaką biurų ir apartamentų aukštybiniuose pastatuose pasirinkimui turèdavo pastato vieta, vaizdas, komfortas, saugumas, prestižo suvokimas, eksterjero architektūra, analogiška situacija yra ir šiandien. Igyvendinant projektą, buvo svarbu, kad už patalpų nuomą gautas pelnas viršytų žemès sklypo kainą, pastato statybos ir eksploatacines išlaidas. Neretai aukštybiniai pastatai, kuriuose buvo ịsikūrusios didelès korporacijos, atlikdavo reklamos, rodančios firmos ekonomini potencialą, funkciją. Šiu pastatu fasadai pasižymejjo dekoracijų, būdingų praeities architektūros stiliams, gausa. Kartais jie turi kompanijos logotipą ar pavadinimą, esantị pačiame pastato viršuje. Šią idèją puikiai atspindi Banker's Trust pastatas. Vèliau tokia kompanijų reklamos forma išplito visame pasaulyje kartu su tarptautinio stiliaus aukštybiniais pastatais. Kartais dangoraižiams būdingos tam tikros išskirtinès architektūrinès detalès, pavyzdžiui, AT\&T, Chrysler pastatai. Išskirtiniai pastarojo pastato apdailos elementai paremti Chrysler firmos gaminamų automobiliu ratų gaubtų išvaizda. Dangoraižis Vakarų valstybèse tapo ne vien tik iššǔkiu statytojams, techninio bei pramoninio šalies potencialo išraiška, bet kartu unikalia kapitalizmo ir jo vertybių išaukštinimo forma. Tačiau pokyčių baimè lèmé poreikị išsaugoti to meto miestams būdingus siluetus, užkertant kelią nevaržomam aukštybinės statybos procesui ateityje, todèl XIX a. pabaigoje JAV aukštybinę statybą lydèjo ir pirmieji aukščio apribojimai. Svarbiausias pasiekimas buvo miestų skirstymas ị specializuotus rajonus, nustatant žemès sklypų paskirtị (Lewis 1998). XX a. pradžioje išryškèjo ankstyvoji konkurencija tarp Niujorko ir Čikagos, statant aukštybinius pastatus. Niujorkas neišgyveno gaisro ar kitokio pobūdžio suniokojimų, kurie galètų intensyviai stimuliuoti daugelio naujų pastatų atsiradimą, todèl pagrindiniu veiksniu tapo imigrantų antplūdis, paspartinęs verslo augimą (Douglas 2004). Išaugus biurų poreikiui, susidurta su statyboms skirtos žemès trūkumu, kuris lèmè vis aukštesnių pastatų statybas. Tai lèmé miesto geografinè padètis, kur statyboms skirta teritorija atliko svarbų vaidmeni, kurị taip pat nulèmé dar kolonijiniu laikotarpiu susiformavęs gatvių tinklas. Didelę itaką aukštybinių pastatų raidai padarè $1916 \mathrm{~m}$. Niujorke ịsigaliojusios zonų išdèstymo taisyklès, kuriomis buvo siekiama reguliuoti miesto plètrą ir taip sustabdyti masyvių pastatų, tokių kaip Equitable, statybas ateityje. Pagal naujas taisykles pastatai turejo laibèti proporcingai jų aukšstejimui, taip būtų pagerinta apatinių ir viršutinių aukštų insoliacija, tai ypač aktualu esant tankiam miesto užstatymui. Architekto Hugh Ferriss eskizas (1 pav.) iliustruoja, koks galèjo būti maksimalus taisyklių leidžiamas pastato tūris. Tai kartu buvo drastiškas ịsikišimas ị pastatų architektūrą. Daugiau kaip pusę amžiaus galiojusios taisyklès, priešingai negu kituose šalies miestuose, nesuvaržè maksimalaus pastatų aukščio, tačiau nulèmė maksimalius galimus tūrius ir suformavo savitą architektūros akcentą, būdingą 1920-1930 m. statytiems Art Deco stiliaus aukštybiniams pastatams (2 pav.). Todèl pastatyta daugybė garsių pastatų, kurie kartais tik keletą mènesių, o kartais net keletą dešimtmečių būdavo laikomi aukščiausiais pasaulyje. Išskirtine aukštybinių pastatų architektūra yra svarbus veiksnys, formuojantis miesto, atskirų jo dalių vizualinį identitetą. Šiuo metu nei vienas pasaulio miestas neturi daugiau pastatų, kurių aukštis viršija 150 m, negu Niujorkas.

Čikagoje, priešingai negu ankščiau minètu atveju, užstatymo kontekstas augo palaipsniui. Tai lèmė XIX a. pabaigoje prasideję bandymai riboti pastatų, kurie tiesiogiai paveikè miesto silueto transformaciją, aukštį. Augant miestui, keitèsi ir maksimalus leistinas pastatų aukštis, kuriam išaugus, biurų statyba atsigavo, tačiau kai kurių šaltinių teigimu, šie suvaržymai vis dar slopino augančią šalies ekonomiką. 1923 m. ịsigalioję nauji pastatų aukščio apribojimai pastatų ribini aukštingu- 


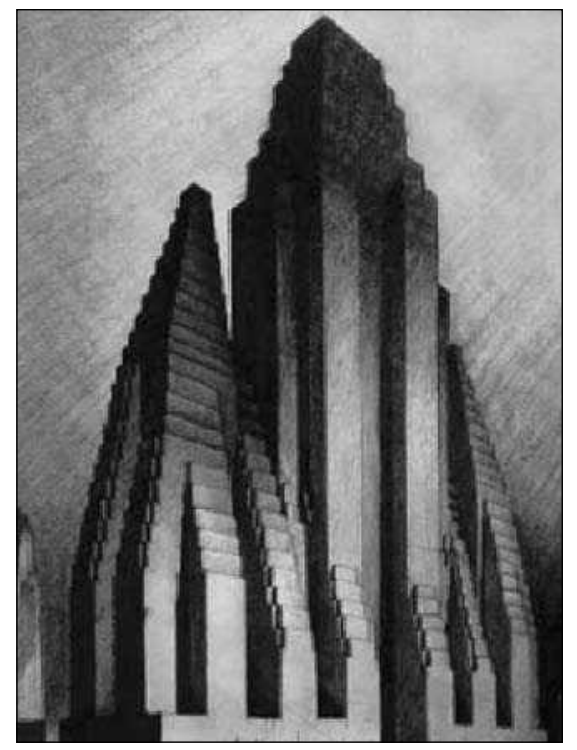

1 pav. Hiugh Feriss 1929 m. eskizas

Fig. 1. Hugh Feriss sketch, 1929

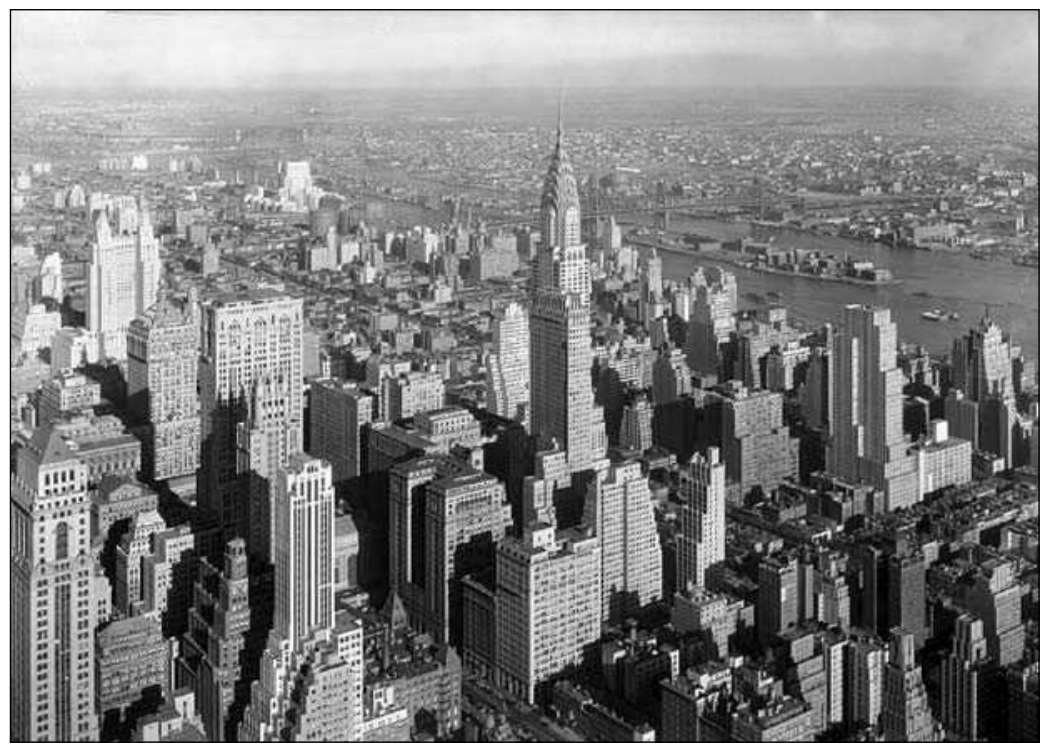

2 pav. Manheteno centras (1932 m.), atspindintis zonavimo taisyklių j̇taką pastatų architektūrai ir miesto plètrai

Fig. 2. Manhattan center of 1932 reflects Zoning Law influence on high-rise building architecture and urban development mą padidino iki 40 aukštų. Šiems pokyčiams didelị poveiki padare ne tik municipaliteto priimtos naujos zonavimo taisyklès, kurios suskirstè miestą i funkcines zonas, nustate joms maksimalų galimą pastatų aukštingumą, kartu pakèlè kartelę tuometiniam miesto užstatymui, bet ir nekilnojamojo turto rinkos augimas. Kapitalistinèse valstybėse nekilnojamojo turto rinka visais laikais turèjo milžiniška poveiki aukštybinių pastatų raidai ir intensyviai šị reiškinị stimuliavo. 1957 m. aukščio suvaržymams Čikagoje tapus laisvesniems, per kitus $15 \mathrm{~m}$. buvo pastatyta daugelis labai aukštų pastatų, įskaitant milžinišką Sears bokštą, kuris net $24 \mathrm{~m}$. išbuvo aukščiausiu pastatu pasaulyje. Naujų vertikalių dominančių atsiradimas patvirtina, kad aukščio ar apimties suvaržymai turejjo tiesioginę itaką:

- miesto silueto pokyčiams;

- panoraminiams vaizdams;

- pastatų aukščiui, architektūrai, planiniams ir tūriniams sprendiniams;

- konstrukcinèms sistemoms;

- pastatų inžinerinei įrangai;

- nekilnojamo turto rinkai.

Kituose JAV miestuose nuo XX a. pradžios maksimalus galimas pastatų aukštingumas pradètas sieti su šalia esančių gatvių pločiu. Vienas tokių pavyzdžių buvo Bostonas, kurio verslo rajonuose statomų pastatų maksimalaus aukščio ir gatvès pločio santykis siekè 2,5 m, tačiau pastato aukštis negalèjo būti didesnis nei $38 \mathrm{~m}$. Kitose miesto vietose jis siekè $24 \mathrm{~m}$ (Lewis 1998). Priešingai negu Europoje, santykis tarp senosios architektūros ir statomų dangoraižių nebuvo akcentuojamas. Nepaisant ịvairaus pobūdžio aukščio suvaržymų, iki pat XX a. pabaigos JAV didieji miestai pirmavo lenktynèse dèl aukščiausio pasaulyje pastato vardo. Aukštybiniu pastatu plètros problemos išliko aktualios iki mūsų dienų, tačiau šiandien nebandoma jų spręsti, siejant galimą maksimalų pastatų aukštị su greta esančiomis gatvėmis ar ịvedant taisykles, turinčias tiesioginę ịtaką architektūriniams sprendiniams. Akivaizdu, kad įvairaus pobūdžio aukščio suvaržymai turejjo lemiamą įtaką miestų siluetų transformacijai. Tačiau nèra vieno, tinkančio visiems nagrinejjamiems atvejams, metodo aukštybinių pastatų plètrai reguliuoti, todèl neretai, atlikus sudètingą urbanistinę analizę, bandoma ieškoti naujų tinkamų sprendinių.

Pokario metais Šiaurès Amerikoje pradèti statyti tarptautinio stiliaus aukštybiniai pastatai smarkiai skyrèsi nuo savo pirmtakų. Šiam laikotarpiui būdingi aukšti, siauri pastatai su aiškiai išreikštu karkasu ir dideliais stiklo plotais fasaduose. Vidinio apšvietimo poreikis padarè didelę itaką architektūriniams ir konstrukciniams sprendiniams. Jie leido transformuotis architektūrai, atsisakyti atgyvenusio akademizmo ir dekoracijomis persisotinusios retrospektyvinès stilistikos. Vietoje masyvių akmeninių išorinių laikančiųjų 
sienų fasadams pradètos naudoti pakabinamos plokštès, kurios turèjo atlaikyti dideles dinaminio pobūdžio apkrovas ir užtikrinti reikiamą komforto lygi pastato viduje. Tai leido sumažinti pastato svorị, atsirado galimybè padidinti kolonų žingsnį ir lengviau išplanuoti vidines pastato erdves. Šie pokyčiai lèmè geresnị patalpų apšvietimą ir galimybę lengviau jas pritaikyti funkciniams poreikiams. Tai užtikrino didesnę naujų biurų paklausą rinkoje, nepaisant brangesnès jų nuomos. Mažéjant pastato konstrukcijų nuosavam svoriui ir didejjant aukščiui, vejjo apkrovos poveikis tapo vyraujantis. Todèl atsirado konstrukcinių sprendinių, kurie ne tik užtikrino pastato stabilumą, bet kartu išreiške jo erdvinę sandarą. Vienas tokių pavyzdžių yra 1957 m. pastatytas Seagram dangoraižis, kuris dešimtmečiams tapo biurų pastato prototipu: <...> Mies van der Rohe sukurti originalios stilistikos pastatai buvo labiausiai tiražuojami pasaulyje, tačiau kopijos ne visada savo kokybe atitiko originala (Магай 2007). Neretai tai buvo daugiau vizualinio pobūdžio panašumai, išreiškiantys pačią modernizmo filosofiją, dominuojančią to laikotarpio architektūroje, o ne pažangius technologinius sprendinius. Galbūt tai reikètų apibrèžti kaip esminę modernizmo stiliaus aukštybinių pastatų problemą, nepaisant jų standartizuotos, monotoniškos išvaizdos.

$<\ldots>$ Niujorke pradetas naudoti naujas sklypu užstatymo būdas, atitraukiant aukštybinius pastatus nuo sklypo ribos ir priešais suformuojant aikšte (Магай 2007). Tam didžiausią ịtaką padarè dar nuo $\mathrm{XX}$ a. pradžios galiojusios zonavimo taisyklès, kurios lèmè tam tikrus architektūrinius sprendinius, visiškai nesuderinamus su dominuojančio tarptautinio stiliaus samprata, ir kèlè šių pastatų plètrai trukdančius reikalavimus. Šalia taisyklingos geometrinès formos aukštybinių pastatų turèjo būti įrengtos aikštès arba juos supti mažesnio aukštingumo pastatų grupès: tai atsispindejo žymiausių to laikotarpio pastatų architektūroje. Tai nebuvo lengva igyvendinti, todèl šie apribojimai nuolat sulaukdavo kritikos iki pat $1961 \mathrm{~m}$. , kai jie buvo pakeisti. Tokie sklypo užstatymo sprendiniai padare poveikị normatyviniams aktams, reglamentuojantiems viešųjų erdvių projektavimą. Tai lèmé žaliųjų plotų miesto plane pagausėjimą. Taip pat ịvyko tam tikri šių pastatų planinių tūrinių sprendinių pokyčiai: $<\ldots$ pagrindiniai pastatu akcentai persikèle iš viršutinès į apatine dali, tai ryškiai atsispindejo to laikotarpio architektūroje (Магай 2007).

Taip pat aukštybinių pastatų architektūroje 6-ojo dešimtmečio pabaigoje ịvyko dideli pokyčiai, susiję su naujais konstrukciniais sprendimais, tokiais kaip išorinès laikančiosios sienos ir centrinis standumo branduolys. Remiantis tais sprendiniais atsirado naujos konstrukcinès schemos (Енделе, Шейнога 1980). Laikančiųjų sienų vertikalūs atraminiai elementai buvo įrengiami nedideliais žingsniais pastato išorejje arba viduje, paslepiant juos už fasado. Vèliau pradètos naudoti vertikaliai arba horizontaliai išdèstytos santvaros. Per trumpą laiką, itin pasikeitus konstrukcijoms, atsirado galimybè lanksčiau išplanuoti vidinę erdvę, kompaktiškai išdèstyti inžinerines komunikacijas pastato plane, įrengiant jas standumo branduolyje. Daugiaaukščiai gelžbetoniniai karkasai pritaikyti ne tik biurams, bet ir gyvenamiesiems pastatams. Siekiant paspartinti statybos procesą pradèta atskirų konstrukcinių elementų standartizacija (Попкова 1973).

$\mathrm{XX}$ a. 7-ajame dešimtmetyje JAV pradèti statyti mišrios paskirties aukštybiniai pastatai, kurių atsiradimui didžiausią įtaką padarè nekilnojamojo turto rinka. Tai suteikè galimybę suderinti kelias pastato funkcijas. Vienas žymiausių tuo metu pastatytų mišrios paskirties pastatų buvo John Hancock centras Čikagoje, pasižymęjęs unikaliais konstrukciniais sprendiniais, kurie lèmé jo išskirtinę estetinę išraišką, nebūdingą to meto aukštybiniams pastatams. Tai vienas sèkmingiausių dèžinès konstrukcinès sistemos pritaikymo pavyzdžių, pasižymėjęs savo išskirtine estetine išraiš$\mathrm{ka}$, unikaliais konstrukciniais sprendiniais, kurie leido itin sumažinti plieno sąnaudas, ịvertinus pastato aukšti (Рафайнер 1982). Tuo metu atsirado ir cilindro formos aukštybinių pastatų, kurie buvo reakcija ị ilgalaikị stačiakampès formos tūrių dominavimą architektūroje. Tai rodè naujų sprendimo būdų paiešką, tūriniai ir planiniai sprendiniai suteikè didesnes išraiškos galimybes: Šiu pastatu konstrukciniu sprendiniu nepaveike standartizacija, todèl ju architektūriniai sprendiniai išliko originalūs ir skirtingi (Иванова 1969). Vienas charakteringiausių to laikotarpio pavyzdžių yra mišrios paskirties Marina city dangoraižis Čikagoje.

$X X$ a. 8-ajame dešimtmetyje JAV pasireiškè viena iš užslèptu biurų paklausos augimo priežasčiu - moteru skaičiaus didejimas darbo vietose, $<\ldots>$ ypač tai pasireišké paslaugu sferoje <...>. Šiuos pokyčius lèmé ịvykę socialiniai pokyčiai visuomeneje (Keating 2001).

Išradus aukštos kokybės plieną, naujus suvirinimo ir sujungimo būdus, atsirado naujų galimybių sumažinti konstrukcijų svorị, taip buvo taupomas laikas ir pinigai ypač tada, kai buvo pateikiami nauji konstrukciniai sprendiniai, kurie leido ateityje siekti naujų aukštumų. 


\subsection{Aukštybinių pastatų raida Europoje}

Nagrinėjant aukštybinių pastatų raidą, iškyla klausimas: kada vis dèl to prasidejo aukštybinè statyba Europoje? Ką turètume laikyti pirmuoju aukštybiniu pastatu? Analizuojant aukštybinių pastatų atsiradimą JAV skirtinguose literatūros šaltiniuose juntamas tam tikras bendras sutarimas šiuo klausimu, o nagrinëjant jų raidą Europoje nuomonès itin išsiskiria. Vadovaujantis skirtingais aukštybinių pastatų apibūdinimo kriterijais, jų raidos atskaitos taškas gali keistis ne vienu šimtmečiu, kartu ir miesto urbanistinè situacija, socialiniai bei ekonominiai veiksniai, galiausiai atlikus analizę galima gauti visiškai skirtingas jų atsiradimo priežastis, veiksnius, intensyviai stimuliavusius ši procesą. XIX a. pabaigoje, pastačius kelis labai aukštus viešbučius Londone (vienas jų didžiausias to meto viešbutis pasaulyje Grand midland), statytojai greitai gavo pastabų dèl aukštingumo iš karalienès Viktorijos administracijos. Jose buvo išreikšti susirūpinimai dèl šių pastatų estetikos ir priešgaisrinių reikalavimų. Todèl buvo priimtos taisyklès dèl pastatų aukštingumo apribojimo, kurios su tam tikromis išimtimis galiojo iki 1950 m. (Wright 2006). Dèl panašių priežasčių XX a. pirmojoje puseje aukštybinè statyba buvo varžoma ir kituose Europos miestuose, tačiau pasitaikè ir keletas išimčių. Tarp jų 1932 m. pastatytas 26 aukštu KBC biurų pastatas Antverpene, kuris dèl savo išskirtinio aukščio literatūros šaltiniuose nurodomas kaip pirmasis dangoraižis Europoje. Nors jis turèjo analogišką konstrukcinę sistemą kaip ir Šiaurès Amerikoje statomi aukštybiniai pastatai bei kitus jiems charakteringus komponentus, tačiau savo aukščiu jiems labai nusileido. Tuo metu, kai Europoje buvo žengiami pirmieji žingsniai, suvaržyti tradicijų ir valdžios institucijų priimtų taisyklių, tikrieji dangoraižiai, statomi JAV, varžėsi tarpusavyje, siekdami naujų rekordų. Tai galima motyvuoti tuo, kad veiksnių, galinčių intensyviai stimuliuoti šių pastatų raidą, Europoje poveikis buvo nepakankamas, todèl apsiribota tik pavienių aukštybinių pastatų išdèstymu miesto plane.

Tačiau jau tada vyko teorinio lygmens diskusijos dèl jų vaidmens planuojant miestus. Nepaisant pokyčių, ivvkusių Europos didmiesčiuose, $<\ldots>$ senamiesčiai atrode labiausiai apleistomis ir atsilikusiomis miesto vietomis, kur suplaukdavo didžiausias transporto srautas ir didelis gyventoju skaičius (Staniūnas 2005). Istoriškai susiklosčiusiam teritorijos užstatymui buvo būdingos pačios siauriausios, kreiviausios ir sunkiausiai pravažiuojamos gatvès, žemiausias užstatymas, taip pat blogos apšvietimo ir vẻdinimo sąlygos: $<\ldots>$ to meto architektūros žvaigždès neleido sau palikti senamiesčiu nuošalyje, todèl 1925 m. Le Korbiuzjè, būdamas vienas pirmuju dangoraižiu šalininku, pasiūlè paskelbti tikra kara istoriškai susiklosčiusiems miestų centrams, visiškai neatitinkantiems užstatymo avangardistiniu tendencijų <...> (Staniūnas 2005). Todèl jis visuomenei pateikè Paryžiaus centro rekonstrukcijos projektą, dar žinomą kaip Vuazen planas (Plan Voisin), <...> kuriame siūlyta nugriauti senamiesti, ǐšskyrus svarbiausius pastatus, ir užstatyti šią teritorija naujai - želdiniuose skendinčiais dangoraižiais <...> (3 pav.) (Staniūnas 2005). Tai buvo gana drastiškas susidariusios situacijos sprendimo būdas, kurị realizavus būtų padaryta nepataisoma žala. Miesto centrinès dalies rekonstrukcija atrodè tarsi panacèja, galinti išspręsti urbanizacijos proceso sukeltas problemas. Dangoraižiai buvo išdèstyti dideliais atstumais, sukuriant žalius plotus, transporto mazgus ir gatves tarp jų. Šiam kaip ir kitiems XX a. pradžioje atsiradusiems miestų rekonstrukcijų planams didžiausią i̇taką turèjo automobilio išradimas. Nors urbanistinė situacija pasaulio didmiesčiuose iki XXI a. pradžios labai pasikeité, tačiau jų plètros problemos, pritaikant senamiesčius šių dienų poreikiams, išliko aktualios iki dabar. Vystant aukštybinę statybą Europos miestuose, šiandien kaip niekad aktualus tapo bandymas apibrèžti senosios ir naujosios architektūros santyki, kuris neretai tampa aršių diskusijų objektu.

Vakarų Europoje iki 6-ojo dešimtmečio pradžios susidare nauja integruoto urbanizmo miestų plètros koncepcija, kuri suteikè galimybę dideliam gyventoju skaičiui dirbti šalia gyvenamosios vietos ir visą parą užtikrinti pilnavertị miesto kaip vientiso organizmo

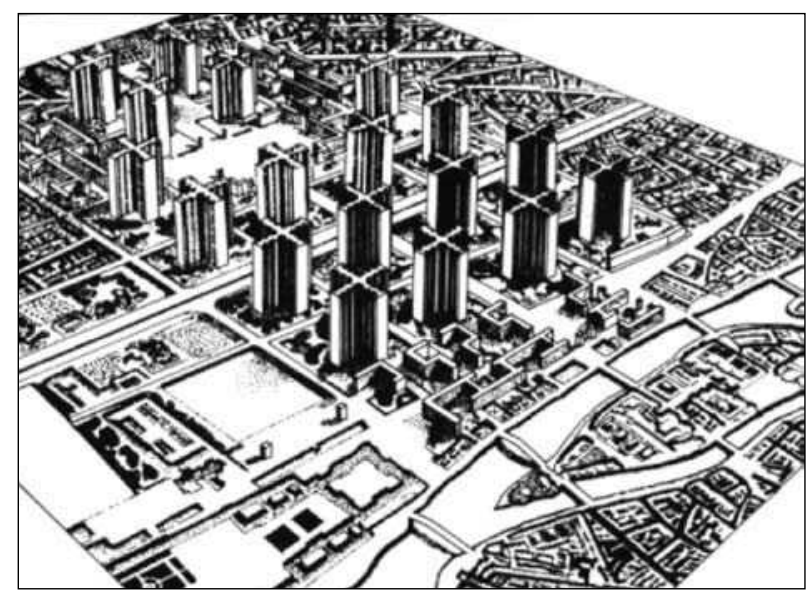

3 pav. Paryžiaus centrinès dalies rekonstrukcijos planas (archit. Le Korbiuzjè, 1925 m.)

Fig. 3. Reconstruction Plan of Paris central district, 1925. Architect Le Corbusier 
funkcionavimą: aukštybinių pastatų projektavimas nebuvo susietas su bendra miesto plettros koncepcija. Apsiribota tik pavienių pastatų statyba didmiesčių centruose, pažeidžiant istoriškai susiformavusius miestų siluetus. Taip nutiko Milane, pastačius pirmąji Europoje aukštybinių pastatų kompleksą, kurị sudarè tarptautinio stiliaus biurų pastatai. Vèliau tokiu principu aukštybiniai pastatai nebuvo projektuojami, išskyrus tarptautinių organizacijų kompleksus, pastatytus Vienoje, Briuselyje, Strasbūre, kurie virto specializuotais verslo rajonais. Europos miestuose susiformavo naujas požiūris į aukštybinius pastatus, kurių pagrindine savybe tapo kompleksiškumas. Nuspręsta atsisakyti iki tol nepasiteisinusios amerikietiškos praktikos užstatyti miesto centrą vienos paskirties aukštybiniais pastatais. Europoje aukštybiniai pastatai atliko ne mišrią paskirtị, o administraciniai pastatai, viešbučiai ir gyvenamieji namai buvo sujungti $\underset{i}{\mathrm{i}}$ kompleksus. Taigi tapo imanoma sujungti įvairių tipų pastatus nepriklausomai nuo aukštų skaičiaus: <...> Londone, priešingai nei kituose Europos miestuose, kur pastatai büdavo kuriami, atsižvelgiant į vietoves ypatumus, laikytasi Šiaurès Amerikai būdingu aukštybiniu pastatu projektavimo tradicijų <...> (Wood 2007), tik paskutiniais dešimtmečiais šios tendencijos pradèjo keistis. Akivaizdu, kad išskirtinès architektūros pastatai, tokie kaip Swiss Re, gali būti naujų tendencijų projektuojant aukštybinius pastatus pavyzdys. Atsižvelgdami į išskirtinę Europos didmiesčių situaciją, miestų projektuotojai nusprendẻ aukštybiniais pastatais užstatyti miestų pakraščius, taip siekdami užtikrinti tolesnę jų plètrą, nepažeidžiant istoriškai susiformavusio silueto. Aukštybinių pastatų iškèlimas iš istorinio miesto centro į buvusius pramoninius rajonus arba ị statybos miesto teritorijas, kurios buvo visiškai sugriautos karo metu, tapo savaime suprantamu dalyku. Neretai būdavo susiduriama su tam tikromis problemomis, kurios visiškai nebūdingos JAV didiesiems miestams. Tai neigiamas vizualinis poveikis istoriškai susiformavusiems miestu siluetams. Vienas tokių pavyzdžių yra 1973 m. Paryžiaus istoriniame centre pastatytas $210 \mathrm{~m}$ aukščio dangoraižis Tour Montparnasse, kuris savo laiku sulaukè nemažai kritikos. Po dviejų diskusijų metų aukštybinių pastatu statyba miesto centre buvo uždrausta. Iš tikrųjų galima tik svarstyti, kada pirmą kartą praktikoje susidurta su aukštybinių pastatų keliamomis problemomis, nustatant santykị tarp senosios ir naujosios architektūros. Ką reikètų laikyti kritiniu momentu, privertusiu pakeisti požiūrị i a aukštybinių pastatų plètrą ir jų vaidmeni Europos miestuose? Matyt, galima įvardinti, kad Europoje tai nutiko XX a. 8-ajame dešimtmetyje suinten- syvejus aukštybinei statybai ir pradëjus artèti link miesto istorinio centro. Tačiau tai ne vienintelè priežastis, apsunkinanti aukštybinių pastatų raidą Europos didmiesčiuose. Per ilgus šimtmečius susiformavusi urbanistinè situacija neleido tinkamai plètoti infrastruktūros, kuri būtina aukštybinių pastatų statybai. Tapo akivaizdu, kad šiuolaikiniam verslui, kuris tiesiogiai siejamas su dideliu biurų poreikiu, žmonių ir transporto srauto koncentracija yra gana ankšta tokiuose miestuose, tačiau reikia pripažinti, kad jis negali būti plètojamas užmiestyje. Todèl iškyla natūralus klausimas, kaip sukurti naują, modernų centrą, išsaugant senąją architektūrą. Tai neretai tampa svarbiausiu aukštybinių pastatų vietos parinkimo aspektu. Sprendimu tapo $1975 \mathrm{~m}$. pradètas statyti La Defense verslo rajonas Paryžiuje, $i$ kurị persikèlè daugelis ịmonių iš centrinès miesto dalies. Nuo nepasiteisinusio taškinio miesto centro užstatymo aukštybiniais pastatais buvo pereita prie koncentruoto, iškeliant juos ị miesto pakrašț̣ ir netaikant jokių aukščio suvaržymų. Anksčiau aukštybinių pastatų statyba Europoje buvo laikoma teigiamu reiškiniu, atspindinčiu augančią ekonomiką, o 8-ajame dešimtmetyje entuziazmas pamažu išblèso ir užleido vietą abejonèms: $<\ldots>$ biuru pastatai pradeti vertinti kaip neigiami kapitalistų valdžios simboliai, kurie lemè didelę žmoniu ir transporto priemoniu koncentracija vietose, kuriose jie buvo statomi <...> (Магай 2007). Tai iš dalies buvo tarptautinio stiliaus ịkūnijamos monotonijos pasekmè. Toliau tęsèsi paieškos naujų pastato formų, galinčių pakeisti dominuojančias tarptautinio stiliaus stačiakampes formas, kurios nepritapo prie senųjų Europos miestų architektūros. Šis kvartalas tapo kontraversiška naujosios prancūzų architektūros vitrina ir alternatyviu pavyzdžiu kitiems Europos miestams. Šiandien jis sékmingai toliau varžosi savo populiarumu su Londono ir kitų Europos didmiesčių verslo rajonais.

Per dešimtmečius susiformavo pagrindinès aukštybinių pastatų išdėstymo schemos: linijinè, taškinè, koncentruota. Frankfurto centrinė dalis užstatyta administracinès paskirties aukštybiniais pastatais, išdèstytais linijiniu būdu šalia miesto centre vingiuojančios magistralès. Toks užstatymas buvo nulemtas istoriškai susiformavusio miesto kaip Europos finansų centro vaidmens, mieste šiandien susitelkę 400 didžiausių bankų biurai. Galima teigti, kad būtų tikslinga aukštybinius pastatus išdèstyti pačiame miesto centre, atsižvelgiant i tai, kad didmiestis karo metu buvo labai sugriautas, priešingu atveju šis kompleksas būtų nesuderinamas su Frankfurto masteliu ir užgožtų jo istorinị siluetą bei kraštovaizdị. Miesto atstatymas pokario metais negrižžmai pakeitè jo architektūrinị veidą. Tam buvo 
pasitelktas modernizmo stilius, tik kai kuriuos pastatus pavyko atkurti autentiškai, todèl centrinèje miesto dalyje atsirado galimybė suformuoti naują verslo rajoną su aukštybiniais pastatais ir pritraukti privačias investicijas. Remiantis Frankfurto aukštybinių pastatų strategija numatytos aukštybinių pastatų išdėstymo vietos, kurios pabrèžè miesto spindulinę struktūrą. Linijinis šiu pastatų išdèstymo būdas pasirinktas ir Roterdame, magistrales pakeičiant mieste esančiais kanalais. Aukštybinès statybos pavyzdžiai Vakarų Europos miestuose parodo, kad nuo funkciškai pagrịstos šiems pastatams skirtos vietos parinkimo priklauso miesto plètros perspektyvos ateityje, galima jo silueto transformacija ir panoraminiu vaizdų pokyčiai.

Sovietų Sąjungoje XX a. pradžioje pasirodè keletas aukštybinių pastatų eskizų, tačiau šie projektai taip ir nebuvo igyvendinti. Žymiausias iš jų buvo sovietų rūmų dangoraižis, kuris turejjo prilygti aukščiausiems to meto pastatams. Tačiau aukštybinius pastatus Sovietų Sąjungoje pradèta statyti po Antrojo pasaulinio karo. Šie pastatai sujunge savyje rusiško baroko, gotikos elementus ir antrojo dešimtmečio JAV aukštybinių pastatų technologiją. Pasirinktas stilius geriausiai išreiškè totalitarinio režimo didybę. Monumentalius architektūrinius sprendinius lèmè totalitarinio režimo pergalè Antrajame pasauliniame kare, kuri buvo susieta su anksčiau pradèta Maskvos miesto rekonstrukcija. Sèkmingai pradèta realizuoti aukštybinių pastatų išdèstymo sistema (4 pav.), kuri buvo patvirtinta $1947 \mathrm{~m}$. specialiu sovietų valdžios sprendimu. Šių pastatų, išdèstytų svarbiausiose kompozicinèse miesto vietose, statyba tapo reikšmingu miestų planavimo ivykiu: Sovietines epochos dangoraižiai tapo savotišku to laikotarpio architektūriniu ženklu, formuojančiu savita miesto centrinès dalies silueta. Tai pakeitè kartu miesto periferiniu teritoriju užstatymo masteli (Gaudutis et.al. 2008).

$\mathrm{XX}$ a. pabaigoje, ivykus politiniams ir socialiniams bei ekonominiams pokyčiams Rusijoje, atsirado galimybė pereiti prie naujos kartos aukštybinių pastatų statybos. İvairiuose šalies didmiesčiuose šis procesas sukèlè nemažai diskusijų ir susirūpinimų dèl tokių pastatų tikslingumo. Maskvos miesto plètros programoje artimiausiems $15 \mathrm{~m}$. numatyta aukštybinè statyba, kuri siejama su periferinemis miesto zonomis, atsiradusiomis per 40 masinės daugiabučiu gyvenamųjų namų statybos pagal tipinius projektus metų. Maskvos savivaldybès patvirtinta aukštybinių pastatų išdèstymo schema ịteisina taškini aukštybinių pastatų išdèstymo būdą periferinèse miesto zonose ( 5 pav.). Tai lèmè dar 1990 m. sostinès valdžios priimtas sprendimas Maskvą paversti pasaulinio lygio miestu. Aukštybinè statyba ne tik skirtingų sričių mokslininkų tyrimų rezultatas, kuriam tiesioginę įtaką turi racionalus, harmoningas pastatų išdèstymas miesto struktūroje, bet ir investuotojų noras gauti kuo didesni pelną, atsižvelgiant $\mathfrak{i}$ esamą padèti nekilnojamojo turto rinkoje. Iš tikrųjų verslo įtaka kur kas pavojingesnè miestams, neturintiems aiškios aukštybinių pastatų plètros koncepcijos, apibrežtos teritorijų planavimo dokumentuose, kai

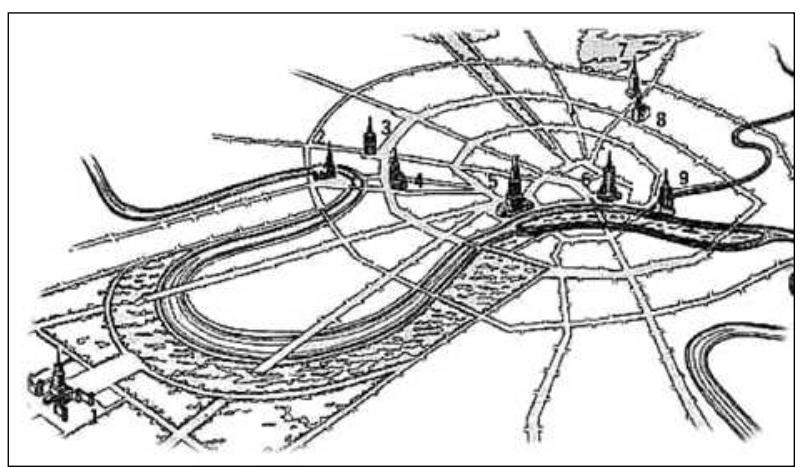

4 pav. Pokario metais (1947 m.) parengta aukštybiniu pastatų išdèstymo Maskvoje schema

Fig. 4. Postwar scheme of high-rise building location in Moscow, 1947

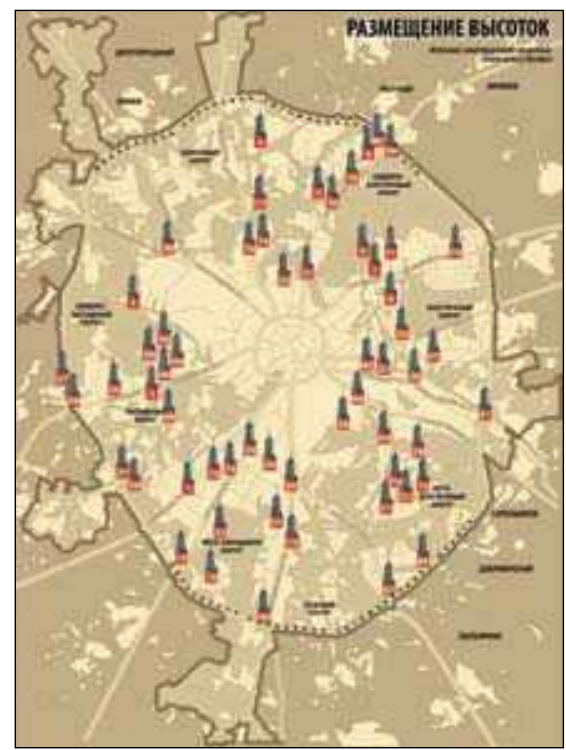

5 pav. Maskvos miesto savivaldybès patvirtinta pastatų išdèstymo Maskvoje schema

Fig. 5. High-rise building location scheme approved by Moscow City Municipality 
svarbius sprendimus priima politikai, atstovaujantys tam tikrų investuotojų grupių interesams.

Lietuvai atgavus nepriklausomybę XX a. paskutiniame dešimtmetyje, augant šalies ekonomikai, prasidèjo aukštybinių pastatų statyba centrinëje Vilniaus miesto dalyje. Jo pakraščiai kaip ir kitose Europos valstybėse jau anksčiau pradèti užstatinèti daugiaaukščiais ir pavieniais aukštybiniais pastatais, siekiant išspręsti dar sovietiniais metais išaugusį gyvenamojo ploto poreikị. Tuomet tai buvo daugiausiai praktinio, o ne estetinio pobūdžio urbanistiniai sprendiniai Vilniuje. Naujų pastatų atsiradimui didelę ịtaką padare politiniai sprendimai, taip pat efektyvi privačių investuotojų veikla. Didejjantis pastatų aukštingumas ir ypač naujo tipo statinių atsiradimas sukelia realų pavojų jau susiformavusiam miestovaizdžiui, kuris gali iš esmès pasikeisti per labai trumpą laiką. Šiems pastatams pradèta skirti daugiau dèmesio, nes jie matomi iš tolimų taškų ir dažnai tampa orientyrais, formuojančiais ne tik lokalias erdves, bet ir panoraminius miestų vaizdus (Daunora et. al. 2004). Atsižvelgdami ị užsienio šalių patirtị galime teigti, kad šie pastatai atgaivina nelabai patrauklius, neretai užmirštus miesto rajonus, paversdami juos naujais verslo centrais. Akivaizdu, kad tokią praktiką būtų naudinga vystyti Vilniuje, konvertuojant mieste esančias nepatrauklias erdves į naujus verslo centrus, išnaudojant aukštybinès statybos privalumus. Siekiant reguliuoti aukštybinių pastatų plètrą, išvengiant chaotiškos jų dispersijos, $2004 \mathrm{~m}$. Vilniaus miesto savivaldybès taryba patvirtino aukštybinių pastatų išdèstymo schemą, kurioje numate koncentruotą užstatymo aukštybiniais pastatais būdą skirtinguose miesto vietose. Šiuo pavyzdžiu netrukus pasekè ir kiti didieji Lietuvos miestai. Rengiant specialiuosius planus buvo siekiama išsaugoti vertingus vizualinio identiteto elementus - siluetą ir panoramas - svarbiausius sudedamuosius miesto kultūrinio tapatumo ženklus. Tai turètų padèti ateityje išvengti aukštybinių pastatų netinkamose miestų vietose. Aukštybinių pastatų architektūrinei išraiškai nẻra būdinga stilių ịvairovè, priešingai negu senas statybos tradicijas turinčiose Vakarų šalyse. Šiuolaikinių administracinių pastatų išraiškai būdingos originalios formos, susijusios su reklama, noru pabrěžti firmos reikšmingumą, aplenkti konkurentus, paieškos. Pagrindine naujų aukštybinių pastatų savybe tapo kompleksiškumas. Remiantis Vakarų Europos pavyzdžiu, juos pradèta jungti i kompleksus su žemesniais pastatais, taip jie padaromi integruota didmiesčių dalimi. Lietuvos aukštybinių pastatų architektūrą smarkiai veikia užsienio šalių pavyzdžiai, tačiau juntamas savitas vietinių architektų braižas, matomi originalūs šiuolaikiški jų sprendimai. Šalia pabrèžtino originalumo jų architektūroje matyti daug naujų pažangių sprendimų, kuriuos lemia darni architektūros, meno ir naujų statybos technologijų sąveika. Laikui bègant nuo eksperimentavimo atsiradusiomis naujomis medžiagomis buvo pereita prie brandesnès aukštybinių pastatų architektūros.

\subsection{Aukštybinių pastatų raida Azijoje}

Azijos žemyne pirmieji aukštybiniai pastatai pradèti statyti XX a. 3-ajame dešimtmetyje. Tai buvo viešbučių ir biurų paskirties pastatai, tokie kaip Šanchajaus parko viešbutis Kinijoje ir HSBC pastatas Honkonge, skirti užsienio kompanijų verslo interesams igyvendinti. Minèti pastatai savo aukščiu negalëjo konkuruoti su tuo metu JAV statomais dangoraižiais. Aukštybinių pastatų statyba po Antrojo pasaulinio karo Azijos žemyne prasidèjo tik nuo $1950 \mathrm{~m}$. Ypatingą išraišką aukštybinè statyba ịgijo miestuose valstybèse Honkonge, Singapūre, kurie laikomi rytų finansiniais centrais. Sparčiai vystantis ekonomikai, daugejjant gyventojų ir esant žemès, tinkamos statybai, trūkumui, atsirado poreikis tankinti esamą miesto užstatymą, plètojant aukštybinę statybą. Honkongas XX a. 9-ajame dešimtmetyje išgyveno aukštybinių pastatų statybos bumą, kuris neatsiejamas nuo šalies ekonomikos augimo, kuriam XX a. pabaigoje didelę itaką padaré globalizacija. Per kelis dešimtmečius miestai pademonstravo beprecedentị augimą. Taip pat labai svarbus ir socialinis klimatas. Kaip ir kituose pasaulio regionuose, Azijoje valstybių išsivystymo lygis yra skirtingas, priklausantis nuo jos dydžio, didelių kultūros skirtumų, aplinkos, istorinių ryšių ir valstybės sistemų. Kinijoje valstybès įtaka rinkai pasireiškia politiniais sprendimais, kuriais nurodomas šalies vystymosi būdas, t. y. laisvų ekonominių zonų, kurios stimuliuoja šalies ūkio raidą bei skatina investicijas iš užsienio, įkūrimas ir plètra. Gyventojų skaičius Kinijos miestuose pradejo itin augti po 1979 m. pradètų politinių reformų, kurios paskatino šalies ekonomikos raidą ir leido sukurti daug naujų darbo vietų. Globalizacija, prekyba ir pramonè, paremta naujausiomis technologijomis, pakeite šalies ūkio prioritetus, nuo tradicinių agrokultūrinių gamybos metodų buvo pereita prie besiremiančių pažangiomis technologijomis ir informacija. Taigi Kinijoje kaip ir visame Azijos žemyne sparčiai išplito milijoninių miestų, kurie kartu tapo politinių ir ekonominių procesų centrais, fenomenas. Dangoraižiai dažniausiai statomi tankiai apgyvendintuose didmiesčiuose, kur, vykstant intensyviam urbanizacijos procesui, jaučiamas statyboms skirtos žemès trūkumas, taip bandoma spręsti aktu- 
alią biurų ir būsto trūkumo problemą. Žemès sklypai tokiose vietose yra be galo brangūs, todèl architektai ir konstruktoriai, maksimaliai išnaudodami užstatyti leidžiamą plotą, veržiasi aukštyn. Globalinè hiperurbanizacija, siejama su gyventojų pajamų augimu, yra neišvengiamas reiškinys, negrį̌tamai XXI a. transformuojantis didžiųjų Azijos miestų plètrą. Jeigu pastarųjų dešimtmečių tendencijos nesikeis, išsivysčiusių šalių gyventojų skaičius miestuose artimiausius $25 \mathrm{~m}$. augs gana nežymiai, tačiau kituose pasaulio regionuose šis procesas vyksta dideliu tempu. Skeptikai teigia, kad tai nèra visiškai natūralus procesas. Šis intensyvios urbanizacijos reiškinys siejamas su staigiu ekonomikos šuoliu Azijos valstybėse. Neretai staigų ekonomikos šuolị lemia lengvai gaunami pinigai ir pakilimas žaliavų rinkoje. Nesudètingas kredito gavimas skatina ekonomikos augimą ir lěšų eikvojimą, kuris leidžia vystytis naujoms technologijoms, sukuriančioms naujas pramonès rūšis arba tiesiog transformuoja esamas, jų struktūrą ir technologijas. Globalizacija leido plèstis ir stiprèti transnacionalinèms kompanijoms, todèl galime teigti, kad tai viena iš pagrindinių priežasčių, kodèl tapo įmanoma ypač aukštų pastatų statyba. Nevengiama aukštybinès statybos centrinėse miestų dalyse, sukuriant kontrastą tarp atskirų firmų pastatų. Kai kurie autoriai teigia, kad nacionalinès vertybės praranda turètą savo reikšmę, kultūrinį identitetą, tačiau nagrinėdami aukštybinių pastatų raidą mes pastebime paradoksalų faktą. Didesnę XX a. dalį miestų siluetuose vyravo paprastų geometrinių formų aukštybiniai pastatai, kuriems įtaką padare tarptautinis stilius arba modernizmo filosofija, apibrežta Bauhaus judèjimo, o naujieji postmodernistinès epochos dangoraižiai tgavo tradicinių nacionalinès architektūros bruožų, atspindinčių patị kontinentą ir jo kultūrą. Šiuos pokyčius geriausiai charakterizuoja Taipei 101 dangoraižis (6 pav.) ir Petronas dvyniai bokštai, kurie sujungia Vakarų ir Azijos šalių architektūros tradicijas. Tai nèra vien tik estetinio pobūdžio pokyčiai, kartu apima planinius ir tūrinius pastatų sprendinius. Nors šiuo metu tai yra tik pavieniai, keliantys susidomejjimą projektai, tačiau šį reiškinị ateityje ịvairiose šalyse norètųsi matyti dažniau. Tai galbūt padètų išlaikyti per šimtmečius susiformavusị kultūrinị identitetą architektūroje, kartu neleidžiama miestams netekti išskirtinių savo bruožų. Gal ateityje šios tendencijos taps nesvetimos ir Lietuvai? Galbūt aukštybiniams pastatams, turintiems vietinès architektūros požymių, lengviau pavyktų užmegzti dialogą su senąja krašto architektūra, taip būtų pabrèžiamas jų tarpusavio ryšys. Tai šiuo metu yra charakteringa Azijos ir Artimųjų

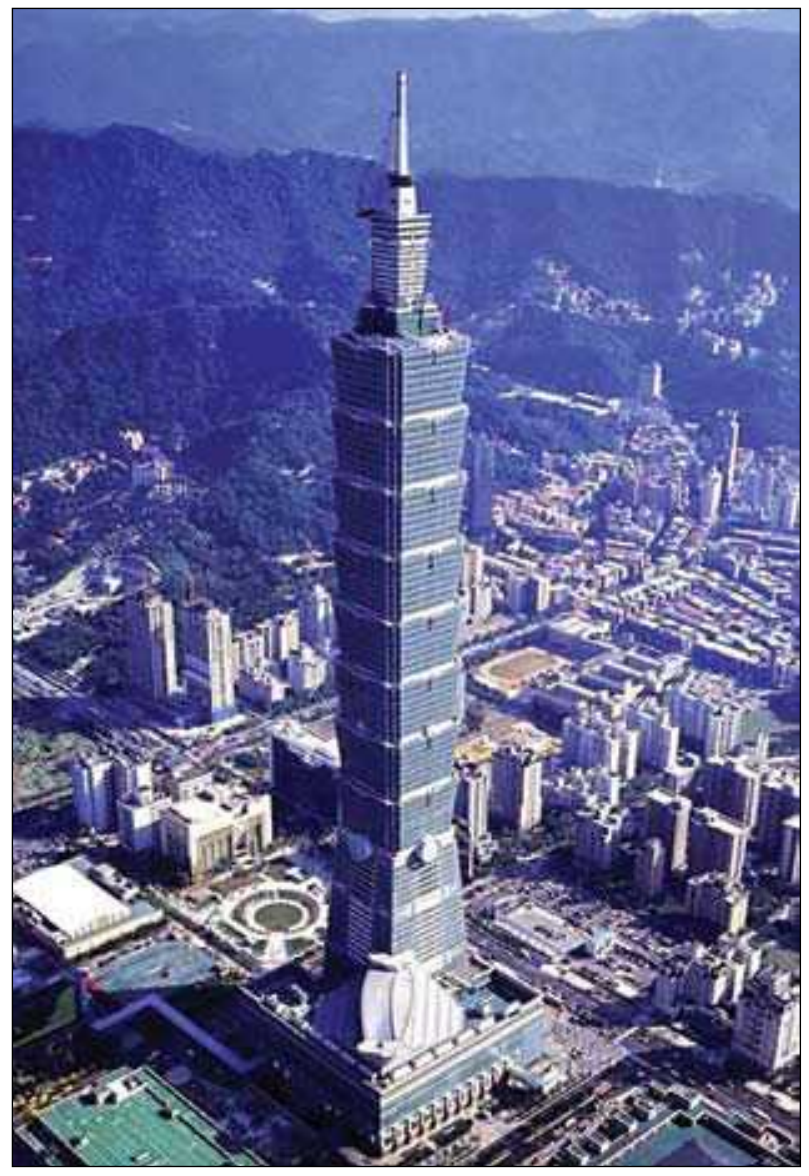

6 pav. Išskirtinès architektūros realizacijos pavyzdys Taipei 101 bokštas Taivanyje (archit. C. Y. Lee, 2004 m.)

Fig. 6. Example of realizing exclusive architecture Taipei 101 Tower in Taiwan, 2004. Architect C. Y. Lee

Rytų miestams. Priešingai negu kai kuriose pasaulio valstybėse, miestų transformacijai buvo tinkamai pasiruošta, skiriant dideles lèšas infrastruktūrai gerinti, viešosioms erdvèms formuoti. Tai vienas iš charakteringiausių urbanizuotos aplinkos elementų, formuojančių šiuolaikinio miesto veidą, kartu tai masalas investuotojams, bylojantis apie mieste veiklą vystančių korporacijų ekonominị potencialą ir atsiveriančias nepaprastas rinkos galimybes.

\subsection{Aukštybinių pastatų pastarųjų dešimtmečių raidos tendencijos}

Dangoraižiai tarsi nekilnojamojo turto rinkos, techninių pasiekimų ir ilgalaikių architektūrinių eksperimentavimų mišinys, reprezentuojantis požiūrị $\mathfrak{i}$ šiuolaikinę architektūrą bei tendencijas ịvairiose pasaulio šalyse. Intensyvus aukštybinės statybos procesas iš Šiaurès Amerikos persikèlè ị besivystančius pasaulio 
regionus. Pastaraisiais dešimtmečiais daugelis aukščiausių pasaulio pastatų tapo mišrios paskirties. Manoma, kad vykstant urbanizacijai tokiu tempu ir toliau, ateityje dangoraižiuose bus įkurti ištisi miestai, siekiant išspręsti gyvenamojo ploto problemą tankiai urbanizuotose vietovese. Tai geriausiai atspindi Normano Fosterio Tūkstantmečio bokšto idèja Tokijaus įlankoje (7 pav.) ir Taisei Construction kompanijos X-Seed 4000 dangoraižis, kurie pralenkia daugelio šiuolaikinių architektų vizijas (8 pav.). Tačiau minèti projektai, matyt, bent jau kurị laiką išliks tik utopijos. Šiuo metu tai galima motyvuoti ne vien tik finansinèmis priežastimis, bet ir techninių galimybių, reikalingų jiems igyvendinti, nebuvimu. Projektuojant ypač aukštus pastatus, susiduriama su tam tikrais sunkumais. Didesnis aukštų skaičius reikalauja papildomų priemonių, siekiant realizuoti konstrukcinius sprendinius, patenkinti gaisrinès saugos keliamus reikalavimus, išspręsti vandens, šilumos ir elektros energijos tiekimo uždavinius, suprojektuoti sudètingas, brangiai kainuojančias ventiliacijos, nuotekų ir šiukšlių šalimo sistemas. Todèl neretai pasirenkamas kiek ekonomiškesnis variantas, t. y. užstatymas vienos paskirties aukštybiniais pastatais, kurie sujungiami ị kompleksus, numatant glaudesni ryši su miesto infrastruktūra. Tokie sprendiniai suteikia galimybę tarpusavyje suderinti ne tik skirtingas pastatų funkcijas, bet ir sumažinti juose dirbančiu žmonių laiko sąnaudas, padidinant darbo efektyvumą. Lietuvos miestams būdingi tiek pavieniai, tiek sujungti ¡ k kompleksus aukštybiniai pastatai, tačiau didžiausias dèmesys skiriamas jų integracijos ị esamą užstatymo kontekstą, kuris nagrinëjamas jau ne vieną dešimtmetị, klausimams. Tačiau, priešingai negu didžiuosiuose pasaulio miestuose, nèra plètojama vertikalaus miesto koncepcija. Tai galima pagristi tokio poreikio nebuvimu bei palyginti lètu ir infrastruktūros požiūriu neretai „skausmingu“ esamos miestų teritorijos įsisavinimu. Nagrinėjant daugiau kaip šimtmetį trunkančią aukštybinių pastatų raidą įvairiose pasaulio šalyse, įžvelgtos pagrindinès jų vystymosi tendencijos:

- pastatai, nekonkuruojantys tarpusavyje savo parametrais, projektuojami, siekiant maksimaliai patenkinti užsakovo poreikius, atsižvelgiant ị susiklosčiusią urbanistinę situaciją;

- pastatai sujungiami ị kompleksus tiek su aukštybiniais, tiek su greta esančiais mažesnio aukštingumo pastatais;

- projektuojami atskiri, dažniausiai mišrios paskirties pastatai, pasižymintys dydžiu, išskirtine architektūra, pažangiausiais konstrukciniais sprendiniais, konkuruojantys tarpusavyje pasauliniu mastu.

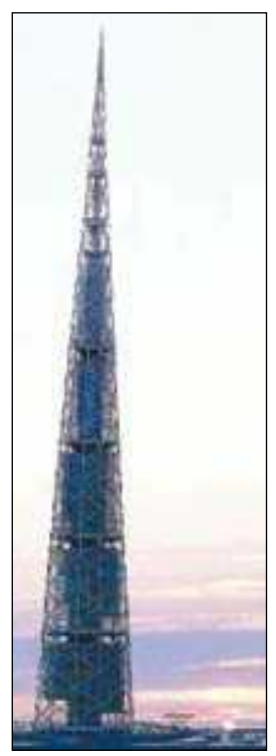

7 pav. Tūkstantmečio bokštas Tokijaus įlankoje (archit. seras N. Fosteris, 1989 m.)

Fig. 7. Millenium Tower in Tokyo Bay, 1989.

Architect Sir N. Foster

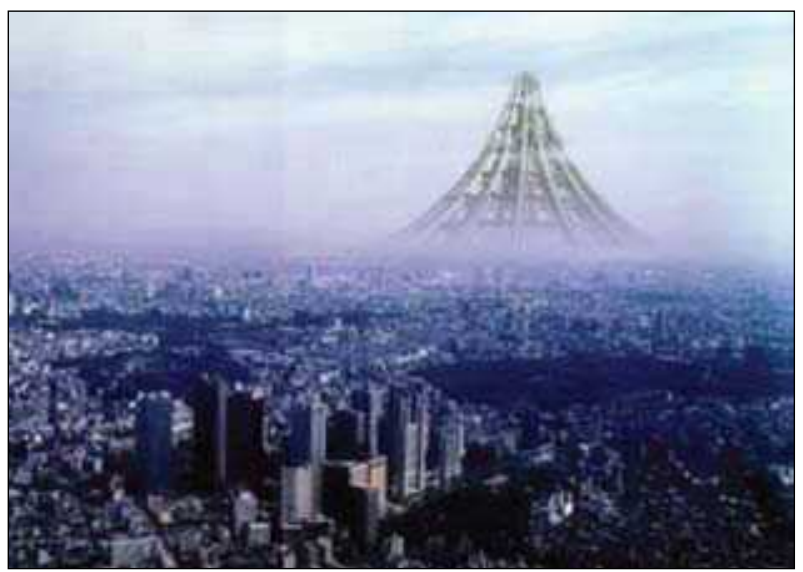

8 pav. $X$-Seed 4000 pastatas Tokijaus uoste (archit. T. Bernstrup, $2008 \mathrm{~m}$.)

Fig. 8. X-Seed 4000 building in Tokyo port, 2008. Architect T. Bernstrup

\section{Išvados}

1. Aukštybiniai pastatai ịvairiuose normatyviniuose dokumentuose ir literatūros šaltiniuose nèra vienareikšmiškai apibrèžti, todèl kyla nemažai sunkumų juos nagrinėjant ịvairiais aspektais. $\mathrm{XX}$ a. antrojoje pusėje aukštybiniams pastatams apibrežti dažniausiai taikomi glaudžiai su gaisrine sauga susiję kriterijai.

2. Atlikus analizę, aukštybiniais galima laikyti tokius pastatus, kurių aukštis nuo žemès paviršiaus iki aukščiausio jų konstrukcijos taško yra 30 ir daugiau metrų. 
Tai atitinka kai kurių visuotinai pripažintų tarptautinių organizacijų ir mūsų šalyje galiojančių normatyvinių dokumentų nuostatas. Kartu pabrèžtina, kad vien šio kriterijaus aukštybiniams pastatams apibūdinti nepakanka, todel reikalingi tolesni tyrimai.

3. Ilgametè aukštybinių pastatų statybos praktika byloja apie tai, kad ju atsiradimas ir raida sietina su toliau nurodytomis aplinkybemis:

- miestų plètra ir gyventojų migracija iš kaimo vietovių i miestus;

- atskirų pasaulio valstybių intensyviu ekonomikos augimu;

- naujų medžiagų, konstrukcinių sprendinių ir technologijų atsiradimu;

- noru reguliuoti miestų augimą ir užstatymo tankị, kurie transformuoja ne tik pastatų architektūrą, planinius bei tūrinius sprendinius, bet ir pasaulio didmiesčių siluetus;

- žemés sklypų kainų augimu;

- miesto gyventojų didesnio komforto poreikiu ir noru sumažinti laiko sąnaudas, skirtas pasiekti darbo vietas bei tenkinti kitus gyvenimo poreikius;

- stambių kompanijų, kai kurių miestų ir valstybių vadovų ambicijomis.

4. Miestų siluetų transformaciją, plètojant aukštybinę statybą, tiesiogiai veikia:

- pastatų aukščio suvaržymo taisyklès;

- susiformavęs gatvių tinklas;

- miesto teritorijos suskirstymas ị rajonus pagal žemès paskirtị;

- atlikti miesto rekonstrukcijų darbai;

- aukštybinių pastatų išdèstymo mieste schemos;

- aktyvi investuotojų veikla.

5. Aukštybinių pastatų architektūrinius planinius sprendinius veikia techninès bei technologinès ir ekonominès galimybės, urbanistiniai miestų vystymosi reikalavimai.

\section{Literatūra}

Council on Tall Buildings and Urban Habitat. Criteria for Defining and Measuring Tall Buildings. 2009 [interaktyvus] [žiūrèta 200901 12]. Prieiga per internetą: <http:// www.ctbuh.org/HighRiseInfo/TallestDatabase/Criteria/ tabid/ 446/Default.aspx.>.

Douglas, G. H. 2004. Skyscrapers - A Social History of the Very Tall Building in America. McFarland. $280 \mathrm{p}$.

Daunora, Z. J.; Kirvaitienè, S.; Vyšniūnas, A. 2004. Vilniaus miesto vizualinio identiteto apsauga ir plètros principai [Preservation of visual identity of Vilnius city and principles of its development].

Vilnius: Technika. $152 \mathrm{p}$.

Eisele, J.; Kloft, E. 2003. High-Rise Manual. Birkhäuser Basel.
Foundation, A. K.; Johnston, P.; Bhabha, H. K.; Aineley, R. 2007. Intervention Architecture-Building for Change. London: I. B. Tauris \& Co Ltd.

Gaudutis, E.; Parasonis, J.; Šipalis, J. 2008. Aukštybiniai pastatai. Architektūros ir konstrukciniu sprendiniu raida [Highrise buildings. Evolution of architectural and construction solutions]. Vilnius: Technika.

Korom, J. J. 2008. The American Skyscraper 1850-1940: a Celebration of Height. Boston: Branden Books.

Keating, R. 2001. High Rise - High Density [interaktyvus] [žiūrèta 200709 10]. Prieiga per internetą: <http://www. ctbuh.org/Publications/TechnicalPapers/tabid/71/language/en-GB/Default.aspx.>.

Lewis, N. P. 1998. Planning of the Modern City. New York: Tailor \& Francis.

Staniūnas, E. 2005. Miestu planavimo nuostatu kaita XX a. Vakaru Europoje [Changes of town planning regulations in XX century West Europe]. Vilnius: Technika.

STR 1.01.06:2002 Ypatingi statiniai, Žin., 2002, Nr. 43-1639.

STR 2.02.01:2004 Gyvenamieji pastatai, Žin., 2004, Nr. 23-721.

Willis, C. 1995. Form Follows Finance - Skyscrapers and Skylines in New York and Chicago. Princenton Architectural Press. 217 p.

Wood, A. 2004. New Paradigms in High-Rise Design [interaktyvus] [žiūrèta 200709 10]. Prieiga per internetą: <http:// www.ctbuh.org/Publications/ TechnicalPapers/tabid/71/ Default.aspx.>.

Wright, H. 2006. London High - a Guide to the Past, present and Future of London's S-kyscrapers. London: Frances lincoln ltd.

Дыховичный, Ю. А.; Казбек-Казиев, З. А. и др. 2007. Архитектурные конструкиии многоэтажных зданий. Москва: Архитектура - С. 248 с.

Енделе, М.; Шейнога, И. 1980. Высотные здания с диафрагмами и стволами жесткости. Москва: Стройиздат. $336 \mathrm{c}$.

Коуэн, Г. Дж. 1982а. Мастера строительного искусства. Москва: Стройиздат.

Коуэн, Г. Дж. 1982b. Строительная наука XIX -XX вв. Москва: Стройиздат.

Козак, Ю. 1986. Конструкции высотных зданий. Москва: Стройиздат. $306 \mathrm{c.}$

Магай, А. А. 2007. Архитектура высотных зданий. Москва: Окей- книга.

Рафайнер, Ф. 1982. Высотные здания: Объемно планировочные и конструктивные речения. Москва: Стройиздат. $180 \mathrm{c.}$

Попкова, О. М. 1973. Конструкиии высотныхзданий за рубежом. Москва: Госстрой СССР, Центральный институт научной информации по строительству и архитектуре. 116 с.

Иванова, Е. К. 1969. Конструктивные решения высотных зданий за рубежом. Москва: Государственный комитет по гражданскому строительству и архитектуре при Госстрое СССР. 56 с. 


\section{ORIGIN AND EVOLUTION OF HIGH-RISE BUILDINGS}

\section{J. Parasonis, E. Gaudutis}

Abstract. Although the evolution of high-rise buildings counts the second centenary, there is no overall criterion used to characterize them. Different are the reasons of their origin and evolution (in view of urbanism, heritage preservation, etc.) in various countries. As a result of analising building code attitudes in some countries and literature sources, in this paper we try to propose a criterion of defining high-rise buildings. The paper also analyses the reasons of their uprise in diferent continents and evolution peculiarities as well as differences in architectural-planning solutions of these buildings in different world cities and their influence on urban development.

Keywords: high-rise building, skyscraper, criteria, architectural and structural peculiarities, city silhouette.

\section{JOSIFAS PARASONIS}

Prof. Dr Habil., and head of Dept of Architectural Engineering of Vilnius Gediminas Technical University (VGTU), Sauletekio al. 11, LT01132 Vilnius, Lithuania.

E-mail: josifas@ar.vgtu.lt

Dr Habil. of Science, First degree in Civil Engineering Kaunas Polytechnical Institute 1962. PhD, Vilnius Gediminas Technical University 1973. Moscow Concrete and Reinforced Concrete Research Institute, 1992. Publications: author and co-author of over 170 research papers. Research interests: structural safety and reliability, architectural and engineering interaction.

\section{ERNESTAS GAUDUTIS}

Master, PhD student, Dept of Architectural Engineering, Vilnius Gediminas Technical University (VGTU),

Pylimo g. 26/Traku g. 1, LT-01132 Vilnius, Lithuania.

E-mail: ernestas.gaudutis@vilnius.lt

MSc, VGTU, 2007. Publications: author and co-author of 3 research papers and 1 study book. 